\title{
Socio-Economic Status of Dalits of the Western Tarai Villages, Nepal
}

\author{
Bhoj Raj Kareriya, PhD \\ Associate Professor, Butwal Multiple Campus \\ bhojrajkareriya@yahoo.com
}

\begin{abstract}
Doms or Dalits living in Tarai region of Nepal are categorized as untouchable according to the Hindu caste system. In other words, they are also defined economically exploited, politically voiceless, socially humiliated, and educationally backward and treated as untouchable castes in the Nepalese Constitution, 2063BS. In the present paper both primary and secondary sources of data have been used. Four VDCs such as Akala, Basantpur, Kamahariya, and Sadi of Rupandehi district have been selected purposively based on the relative representation of the dalits. Altogether 30 Dom households were selected randomly. The paper focuses mainly on analyzing socio-economic condition of the Dom communities and major problems faced by them for livelihoods and at the end, suggestions are provided to raise their living standard.
\end{abstract}

\section{Introduction}

It is needed to identify the community or the caste system to which Dalit groups belong. Castes refer to an occupationally segregated, hierarchically and ritually discriminatory social system based on heredity of an individual or group of individuals. Dalits are known categorically as economically exploited, politically voiceless, socially humiliated, educationally backward and treated as untouchables by the Hindu caste system. The major Dalit groups in the Tarai (southern part of Nepal adjoining to Indian border) are Chamars, Mushahar, Dusadhs, Doms, Sarki, etc. while those in the hills are Damai, Kami, and Sarki. In the Kathmandu valley, the major Dalit castes include Pode and Chyame.

The present paper deals with Dom or Dalit group. The doms are short in stature, dark skinned, having long and loosely kept hair mostly unplaited and the most peculiar feature is their strange glass like eyes (Gautam and Thapa Magar 1994). Their educational status is very poor as they are socially, culturally and economically deprived. The doms are considered the lowest untouchable caste groups of the Terai; they are not allowed to fetch water either from the private or public tube wells. They have separate tube wells for their own use or go to the nearby stream and pond to fetch water (NPC 2002).

The Doms are concentrated more in districts like Morang, Jhapa, Sunsari, Siraha, Saptari, Dhanusa, Mahottari, Sarlahi Bara, Parsa, Rauthat Rupandehi, Kapilvastu, Nawalparasi, Banke 
and Bardiya. The total population of the Dom People in Nepal is 8,931 (0.04\%) where male Doms are 4631 and females are 4300 (CBS 2001).

\section{Objective}

The main objective of this paper is to analyze socio economic condition of Dom community, which is considered as one of Dalit caste groups in Hindu caste system.

\section{Methods of Data Collection and Analysis}

The methods used in the present paper are data collection technique/instruments, sampling procedures and data analysis method. Under the primary sources of data tools like structured questionnaire and interview were used. And also, participant observation technique is conducted directly having participation with the respondents.

Likewise, secondary sources of data are gathered from different published and unpublished materials such as books, research article, research report, CBS, and NPC/N and also related profiles. Key informants are the important source of acquiring real data. Similarly, instruments used in collecting data are interview schedule form for parents; households survey form etc.

\section{Sampling Procedure and Sample Size Determination}

In sampling procedures, the purposive sampling technique is applied to select the study area. Out of 69 VDCs of Rupandehi District, only four VDCs such as Basantpur, Akala, Kamahariya and Sadi have been selected for the study. The total population of Rupandehi district is 708,419 . Of which, 360,773 are males and 347,646 are females, while the related VDCs' populations 6,$631 ; 9,265 ; 15,661$ and 5,246 are in Basantapur, Akala, Kamahaiya and Sadi respectively. But the total population of Dom in the district is 94 . Of which 47 are males and females are also 47. Among which the number of Dom in the VDCs like Basantpur Akala, Kamahariya and Sadi are $22,16,18$, and 16 respectively (CBS 2002).

The nature of the universe was homogeneous and small. So cluster sampling method is applied taking them as a group to collect the data. There were only 30 households in these VDCs, so census method is applied and information is collected from all 30 households.
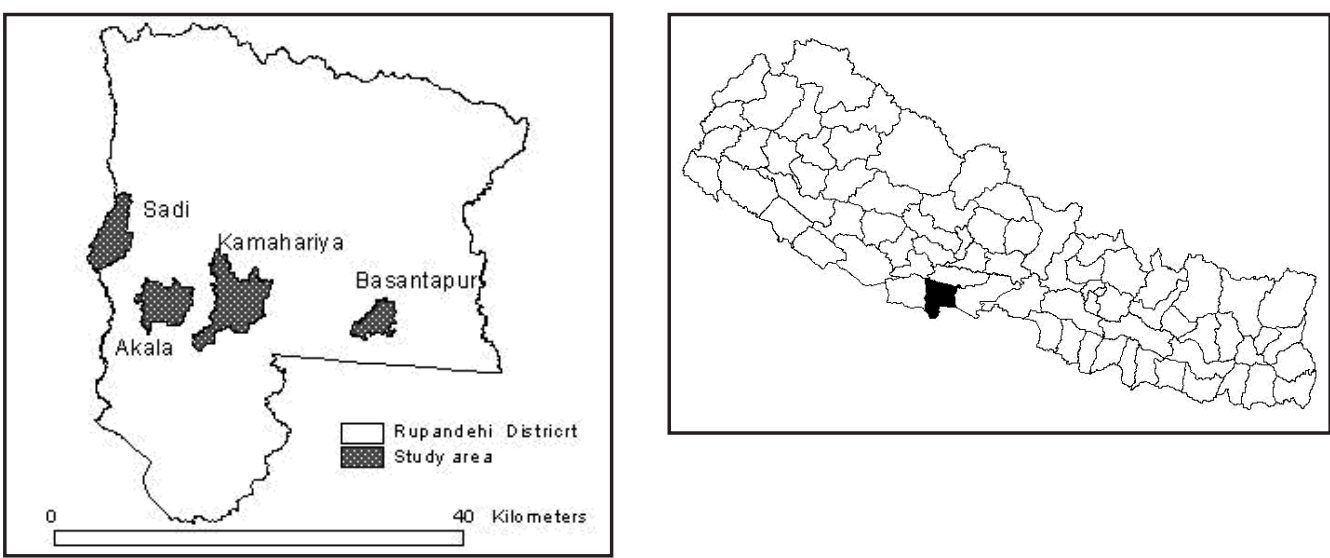


\section{Results and Discussions}

The discussion implies that most of the children of the Dalit communities are unschooled. For this, a question arises that why are they unschooled? Most of the studies pointed that there is lack of cultural capital for their schooling and financial constraint to meet their educational expenses, institutional reluctance to enable them for learning in a blanket form, and contemptuous treatment of the teachers towards the Dalit students. In this regard Regmi (1991) studied on Dhimal Miracles Migrants of Himal about Dhimal and his contribution is a milestone of ethnography of Dhimal community. Likewise, the study made on The Newars" of Kirtipur (Nepali 1965) and The Chepang studied by Gurung (1989) are the prominent literatures to the present study. Similarly, the people of Nepal have given some accounts of untouchable castes of remote western and far western regions (Bista 1996).

Some foreign scholars have tried to write about the untouchable castes, but they all are not ethnographic study. Priest and cobblers is an example which is the study about the social change in Hindu village of Western Nepal (Caplan 1972) and Macdonald (1975) has written a book in which some untouchable castes are focused. Likewise, other scholars like Subedi (1995) have studied Badi following prostitution occupation. Sah (2005) has also prepared dissertation on Chamar, a leather working people of Nepal and Yadav (2005) has also written on the Musahar a cat eating people of Nepal.

After the empirical data collected from the field, the analysis becomes the prominent step for discussion of the result. Demographic characteristics, socio-cultural and economy of the people are directly associated to the households characteristics of the people made as follows:

\section{Population distribution by Age and Sex}

Table 1 reveals five age groups such as $0-5$ years being the non- schooling children, 6-14 school going age, 15-39 years the most active productive age, 40-59 years the less and non- fertile but economically still active age and 60 over as dependent elderly people. The table further indicates that 48.88 percent are males and 51.12 percent are females and their sex ratio is 95.65. Likewise, the lowest population of Dom community is 4.44 percent which Hindu belong to above 60 years age and the highest population is 38.51 percent of 15 -39 age groups which are most fertile and active population. Similarly, age between 0-5, 6-14 and 40-59 are 13.35 percent, 31.85 percent and 11.85 percent respectively.

Table 1: Distribution of Population by Age and Sex

\begin{tabular}{lcccc}
\hline \multirow{2}{*}{ Age } & \multicolumn{2}{c}{ Population size } & \multirow{2}{*}{ Total } & Percent \\
\cline { 2 - 3 } & Male & Female & & \\
\hline $0-5$ & 8 & 10 & 18 & 13.35 \\
$6-14$ & 20 & 23 & 43 & 31.85 \\
$15-39$ & 27 & 25 & 52 & 38.51 \\
$40-59$ & 7 & 9 & 16 & 11.85 \\
$60+$ & 4 & 2 & 6 & 4.44 \\
\hline Total & 66 & 69 & 135 & 100 \\
\hline \multicolumn{2}{l}{ Source: Field survey, 2010} & & &
\end{tabular}




\section{Changes in Socio-cultural life of the Dom Community}

Change is a universal fact, so socio-cultural life of the Doms is undergoing change gradually. Previously, Dom used to live in joint family, but the joint family system is now being decided at the study area. Only 6 families (20\%) out of 30 family households found to live in joint-family and rest of them i.e. 24 families (80\%) are found in nuclear family as they like to live with income which they earn (Table 2 and fig. 1)

The average family size of Dom is 4.5 , which is smaller than the national level average 5.44 (CBS, 2001) It is so because the trend of nuclear family system is very common in the Dom community.

Table 2: Types of family of Dom Community

\begin{tabular}{lccc}
\hline Family Types & Joint family & Nuclear Family & Total \\
\hline No of H/Hs & 6 & 24 & 30 \\
Percentage & 20 & 80 & 100 \\
\hline
\end{tabular}

Source: Field survey, 2010

Similarly, marriage system is also changing as early marriage (babyhood marriage) was in practice is the past, but now it is decreasing gradually. It is found that rites of Doms are also changing in course of time. Due to poverty, they are leaving to celebrate chhaithi $\left(6^{\text {th }}\right.$ day from birth) or nwaran ( $11^{\text {th }}$ day from birth). The parents themselves give name to the baby. Changes are seen in mortuary or death rite because they prefer to bury the dead body rather than burning as it is quite expensive for them. Dom families, celebrate different types of festivals like Dashain, Deepawali, Chhatha, Maghe Sankranti, Holi, Jur Sittal and Chaurachan as they are influenced by the neighboring castes.

In dresses, males wear shirt, paints, jacket dhoti and kurta while married females put on saree, blouse but unmarried females wear suruwal, kurta, shirt t-shirt and maxi. In ornaments female Doms use mangalsutra, ring, ear-ring, bindi, nail polish and bangles. It is found that they use cheaper and low quality of dresses and ornaments as their economic condition is poor.

They follow Hindu religion. Now their ways of worshipping of God and Deities has become quite flexible. It is observed that they did not follow their religion more rigidly. Thus changes in sociocultural life of the Dom community are also found to be the source of motivation to schooling of their children.

\section{Relation of Doms with other castes}

Doms are untouchable as per Hindu caste system. So, they cannot get all social opportunities in Hindu society. None of the clean or high castes get food or water from them and avoid physical contact where possible. But the constitution of Nepal, 2047 and Interim constitution of Nepal 2063 B.S theoretically forbade caste based discrimination in Nepal. However, there is found a satisfactory relationship between the Doms and other castes. The other caste people have necessity to come in the close contact with the Doms for various reasons, i.e. to buy basketry products. 
In the democratic system a single vote is also valuable during election period. So many political parties are in close contact with the Doms in the election period. In this way relation is being nearer and nearer with other caste people in the study area.

Thus, it is opined that Doms as being untouchable caste in the study area, their social status in the society is not as poor as feeling of untouchability is decreasing in comparison to the past. So it can be said that the social status of Doms in the society is gradually improving.

\section{Economic Condition}

\section{Occupation}

Traditionally speaking, Doms are associated with grave digging, cremation of dead bodies and making a variety of baskets from the bamboo and as hereditary occupation, but in the course of time, situation has changed a lot. The Doms are related with making a variety of basket from a bamboo leaving grave digging and cremating dead bodies now.

The young Doms are found to like to work as carpenter, wage labor. Among 30 households, 26 (86.66\%) households adopted traditional occupation but only 4 (13.34\%) households followed other occupation. In the absence of occupation and sufficient income sources, people cannot meet their daily needs and demands for the family. Occupation status plays a vital role in the promotion of individual and community' status. Table 3 gives a glimpse of the occupational status of Doms.

Table 3: Occupation structure of Dom Community in Rupandehi

\begin{tabular}{lrr}
\hline Occupation & Number & Percent \\
\hline Agriculture & 4 & 6.66 \\
Labour (Wage) & 9 & 15.00 \\
Bamboo work & 30 & 50.00 \\
Mason & 12 & 20.00 \\
Carpentry & 4 & 6.66 \\
Service in India & 1 (loom) & 1.68 \\
\hline Total & 60 & 100.00 \\
\hline
\end{tabular}

Sources: Field Survey 2010

Table 3 shows that the main occupations of the Doms are the work of Bamboo which occupies the highest number 30 (50\%). It is followed by mason 12 (20\%), similarly. 15.0 percent and 1.68 percent of the total respondents are closely associated to labour work and working in India respectively and agriculture and carpentry occupation occupy only 6.66 percent each.

\section{Income source}

The income sources of Dom community in the study area are agriculture, indigenous occupation service, wages, livestock rearing, business and others. Of which, 53.33 percent peoples' income sources are from wages while 3.33 percent people earn the money from the services. 


\section{Landholding}

In an agrarian economy, the extent of ownership of land is the main indicator of relative economic status of people. Table 4 gives the land holding pattern of Doms.

Table 4: Description of land Holding pattern of the Doms

\begin{tabular}{lrr}
\hline Size of land (in Kattha) & No of Households & Percent \\
\hline Below 10 & 5 & 16.66 \\
$10-20$ & 6 & 20.00 \\
21 - 40 Kattha & 2 & 6.66 \\
Landless (Except unregistered) & 10 & 33.33 \\
Landless & 7 & 23.35 \\
\hline Total & 30 & 100.00 \\
\hline
\end{tabular}

Source: Field survey, 2010

Table 4 indicates that most of Doms are found landless. Among 30 households, 7 households (23.35\%) are completely landless and 10 households (33.33\%) among them are also landless but they have some unregistered land. Only 5 households (16.66\%) have the land less than 10 Kattha and 6 (20.00\%) have less than 40 Kattha. It is also found that the land which is with Dom is un-irrigated low quality land. Therefore, the productivity is always very low. So they always suffer from food deficiency.

\section{Food sufficiency}

Food sufficiency has been analyzed on the basis of availability of food monthly wise, as presented in Table 5.

Table 5: Distribution of Households by their food sufficiency

\begin{tabular}{lll}
\hline Periods & No. of households & Percent \\
\hline Below 3 months & 9 & 30.0 \\
4-6 months & 4 & 13.13 \\
No of food sufficiency & 17 & 56.67 \\
\hline Total & 30 & 100 \\
\hline
\end{tabular}

Source: Field Survey, 2010

Table 5 shows that among the total households of Doms, only 9 households (30\%) are found to provide less than 3 months of their food requirement from their own agricultural production and only 4 households (13.33\%) who can meet up to 4 to 6 months of their food requirements from their own agricultural production. Similarly, 17 households i.e., 56.67 percent have no any agricultural production because they do not have agricultural land. Thus, it is apparent that Doms cannot survive only on their agricultural production.

\section{Livestock}

Livestock is an important source of income of rural people. It supports the farming activity. It is also a source of protein for people. The importance of domestic animals is not limited only to 
economic aspects. Some animals are said culturally and religiously more important in Hindus society.

In the Dom community, they tame different types of domestic animals but in very few numbers. The number of domestic animals and birds is given in table 6 .

Table 6 depicts that the numbers of livestock per household is found limited. Six different types of domesticated animals are tamed only for domestic consumption but not for commercial purpose. Ox is tamed for ploughing land. Cow and buffalo are kept for dung; milk and their ox/calf are also used as a machine like a local tractor. It is found that the number of livestock is small as there is no forest nearby for cattle raising. Some respondents explained that for cattle raising, the limited land holding is the severe constraint. It is also found that livestock products like milk and ghee is not bought by other castes as Doms are untouchable caste. So, Doms do not like to tame domestic animals in large scale.

Thus, it appears that the animal husbandry to some extent is directly influenced by the limited landholding and Dom being untouchable caste.

\section{Settlement pattern}

Settlement pattern and house structure of Doms are directly or indirectly influenced by socioeconomic condition of Dom. The settlement of Doms is generally located outside the settlement of other high caste people. It may be owning to the ethnic compactness, intolerability and lack of land.

Though, the settlement of Doms in Rupandehi are found compact in nature and most of the houses are built closely but the clustering of houses has no any particular direction as other ethnic groups like Tharus, Telis and Yadavas etc. Due to population increase in settlement areas, it is now going to be insufficient for the construction of new houses.

In the study area, the houses of Doms are made up of mud and thatched roof slopping toward two sides. The houses are found to have only one roof and have no any windows. Pens are made to tame pigs or other animals which lie near the houses of Doms.

The size of the house is very small and narrow because of poverty. The Doms clean their houses mostly once a year, especially in Dipawali (Laxmi Pooja). By the analysis of house types of Doms, it is found that 93.33 percent Doms are living in katchcha houses whereas only 6.67 percent Doms are living in pakka houses (table 7) 
Table 7: Types of Houses

\begin{tabular}{lrr}
\hline Type & No. of households & Percent \\
\hline Katchcha & 28 & 93.33 \\
Pakka & 2 & 6.67 \\
\hline Total & 30 & 100.0 \\
\hline
\end{tabular}

Source: Field survey, 2010.

\section{Social adaptation}

Under the social adaptation citizenship and total registration, social status, adaptation problems and social exclusions are discussed.

\section{Attitude towards getting citizenship and doing vital registration}

All the people of the country have the right to get their citizenships to be a real citizen of the country. Citizenship to be a real certificate of the citizen of the country plays a vital role in daily activities as well as academic and administrative fields (Table 8). Similarly, all the people of the country have the responsibility to register their marriage, birth of children, death of family members in government office like VDC/ Municipality (Table 9).

Table 8: Distribution of the Respondents by acquisition of Citizenship

\begin{tabular}{lcr}
\hline Type & No. of households & Percent \\
\hline Have got citizenship & 36 & 60 \\
Have not got citizenship & 24 & 40 \\
\hline Total & 60 & 100 \\
\hline
\end{tabular}

Source: Field survey, 2010.

Table 8 shows that 60 percent respondents have got citizenship and 40 percent respondents replied that they have not got citizenship.

Table 9: Distribution of the Respondents by doing vital Registration

\begin{tabular}{lcl}
\hline Type & No. of households & Percent \\
\hline Registered & 22 & 36.66 \\
Not Registered & 38 & 63.34 \\
\hline Total & 60 & 100.0 \\
\hline
\end{tabular}

Source: Field survey, 2010

Table 9 depicts that out of the total respondents 60, only 36.66 percent respondents are registered and 63.34 percent respondents are not registered.

\section{Social status of Doms in the society}

As it has already been analyzed that Dom community belong to Hindu religion and regarded as untouchable The upper caste people do not take food and water from them, so Dom community 
has its own tube-well for water. But after 1990 A.D the situation has changed a lot. The feeling of untouchable among young generation is being limited and reduced. During the interview, some Doms told that some male Tharus of the village had come to their home and drunk wine and taken chicken meat made by their hands.

Although, the position of the Doms in caste hierarchy is still low, the feeling of untouchbiity is not rigid as it was in the past. Therefore, it can be said that the social status of the Doms in the society is gradually improving.

\section{Adaptation problems of the Dom Community}

With the change of the time feeling of untouchbiity is not as rigid as it was in the past in the society but the Doms are still facing adaptation problems. First of all, they are Sudra and their traditional occupations are grave-digging, cremating dead bodies and making a variety of baskets from the bamboo which is known as the dirty work.

In the Dom community drinking wine and quarrelling among themselves are very common. During the field work, it has also been observed that they quarreled many times for their type of behaviors, other caste people hate them.

It is also observed that other caste people do not like to give them equal status as themselves. Therefore, adaptation is being difficult for them in the society. Sensing all these problems it is suggested that good education and awareness generating programmes are very essential for them.

\section{Reacting against social exclusion}

Generally, social exclusion means discrimination among different castes concerning with activities which are directly or indirectly associated with a society. The Doms expressed that social exclusion is our problem in the ways of improving and enhancing the life style,

\section{Conclusions}

Among various Dalit groups Doms have been considered as one of the most deprived and low caste groups socially, culturally and economically. Although they belong to Hindu religion, yet they are known as untouchable. Their main occupation is bamboo work; about 50 percent of Dom community is engaged in the work of basketry. Other occupations which they follow are mason (20\%): labour/wages (15\%) agriculture (6.66\%) carpentry (6.66\%). And service in India in hand loom factory (1.68\%). Beside these, they are engaged in livestock rearing too.

Aforesaid description analyses that Doms are categorized in the Hindu caste system even though they are untouchable in the society, so they can not avail all the facilities and opportunities as other castes. This indicates that Doms have poor social status in the society and they have also problem of adaptation in the society. Similarly, it is observed that Doms have poor social status in the society with the problem of adaptation in the society. Similarly, it is observed that Doms have major social exclusion. Problems lead them not to make their qualitative life. Thus keeping these problems and hindrances in mind for improving the standard of Dom community and making their life qualitative the following suggestions are put forward: 
- Awareness programmes regarding untouchbiity should be disseminated.

- Interim constitution of Nepal 2063 B.S. should be effectively implemented regarding Dalits.

- Social exclusion should be changed.

- Government should take policy against social exclusion.

- Government should provide more rights to minority group of Dalits in different fields.

\section{References}

Bista, Dor Bahadur (1996), The People of Nepal. Kathmandu: Ratna Pustak Bhandar.

CBS (2002), National Report. Kathmandu: Central Bureau of Statistics office.

Caplan, A.P. (1972), Priest and cobbler: A Study of Social Change in a Hindu Village of Western Nepal. London: Inter text Books.

Census. (2001), Census of Government of Nepal. Kathmandu: Central Bureau Statistics office.

Gautam, Rajesh and Thapa Magar, Ashok (1994), Tribal Ethnography of Nepal. New Delhi: Book Faith.

Gurung, G.M. (1989), The Chepangs: A Case Study in Continuity and Change. Kathmandu: CNAS, Tribhuvan University.

Macdonald, A.W. (1975), Essay on the Ethnology of Nepal and South Asia. Kathmandu: Ratna Pustak Bhandar.

National Planning commission (2002), National Dalit Strategy Report. Kathmandu: Action Aid Nepal and Save the Children and CARE Nepal.

Nepali, G.S. (1964), The Newars. Kathmandu: Himalayan Book Sellers.

Regmi, Rishi Keshav Raj (1991), The Dhimals, Miracles Migrants of Himal. Delhi: Nirala Publication.

Chamar: A Case Study of Ramnagar Mirchaiya VDC, Siraha Distinct, Nepal. Kathmandu: M.A. Unpublished dissertation submitted to Dept. of Rural Development in Tribhuvan University.

Subedi, Madhu Sudan Sharma (1995), Socio Cultural Strategies of the Badis for Adaptation. Unpublished M. A. Dissertation. Kathmandu: Sociology and Anthropology, Tribhuvan University.

Yadav, C. (2005), Socio-Economic Status of the Musahar: A Case Study of Ramnagar Mirchaiya VDC, Siraha District, Nepal. M. A. Dissertation. Kathmandu: Central Department of Rural Development, Tribhuvan University. 